\title{
Can public-private partnership policy reduce poverty and grow sustainable economies in indonesia? (case study approach)
}

\author{
Ary Miftakhul Huda ${ }^{1, *}$, Antun Mardiyanta ${ }^{2}$, and Erna Setijaningrum ${ }^{2}$ \\ ${ }^{1}$ Master Student of Public Policy Department, FISIP, Airlangga University, Indonesia \\ ${ }^{2}$ Lecturer of Public Policy Department, FISIP, Airlangga University, Indonesia
}

\begin{abstract}
The openness of the investment in Indonesia has become one of the main focuses in supporting the Nawa Cita Program by Jokowi and Jusuf Kalla. Unfortunately, the increase in investment is not balanced with the number of poor urban and rural population in Indonesia. Therefore, social inequality in Indonesia still tends to be quite large. One form of investment is the development of supermarkets. The goal of this study is to analyze the implementation of partnership policies between supermarkets and SME with a case study approach of supermarket chains with SME in Sidoarjo Town, East Java Province. This study uses a qualitative approach, through in-depth interviews on SME who partner with supermarkets in Sidoarjo. The results showed that the government-led partnership policy to improve the economy of society and overcome the gap on the growth of supermarkets did not run optimally. Thus, the Government's goal to create a mutually beneficial business partnership between supermarkets and SME can not be achieved, so that there needs to be an evaluation on the partnership policy made by the Government further so that the partnership policy can be successful.
\end{abstract}

\section{Introduction}

The Minister of Indonesian National Development Planning explained that the poverty reduction plan listed in the SDGs was considered important to be implemented. The three plans are comprehensive social protection, provision and improvement of access to basic services, decent and sustainable livelihoods. Therefore, Indonesia placed the plan in the Nawacita program as a policy priority program during the reign of Jokowi and Jusuf Kalla, namely in the openness of investment.

The growing number of self-service shops in several regions in Indonesia is one of the factors of openness supported by the Government of Indonesia. Investment openness is one of the main focuses in supporting the Nawa Cita Program in the Jokowi-Jusuf Kalla Government, namely through a policy of economic deregulation to encourage quality economic growth, amidst the global economic downturn. This was done through 13

\footnotetext{
*Corresponding author: ary.huda@gmail.com
} 
economic policy packages with 204 provisions, namely Package X (Investment Package) and Package XII (Increasing Ease of Doing Business / EoDB).

The Government's seriousness in increasing investment in total capital during the period of January - December 2017 issued by the Indonesia Investment Coordinating Board [1] amounting to 692.8 trillion Rupiah, which exceeded the target of 678.8 trillion Rupiah. Thus the achievements of the Government are around 102.1\%. This success was also supported by an increase in Indonesia's ranking in the Ease of Doing Business (EoDB) conducted by the World Bank. EoDB is an annual survey conducted by the World Bank that represents the use of resources. Based on [2], Indonesia's rating in the EoDB in 2018 is 72. This means that in 2018, Indonesia experienced an increase in rank from year to year.

However, along with the increase in the amount of investment, it is not balanced by the number of poor people in cities and villages in Indonesia who are converting to a significant decrease. Based on [3], the number of poor urban and rural residents in Indonesia per September 2017 is 26.58 million people. This number decreased when compared to September 2016 which was known to 27.76 million people, but the decline was only around 1.18 million people.

Therefore, social inequality in Indonesia still plays a big role. The phenomenon of social inequality can be done through the ratio of the Gini conducted by the Central Statistics Agency (BPS). As of September 2017, BPS explained that the Gini coefficient was 0.391 . The coefficient of this ratio decreases when compared to September 2016 which is 0.393 . However, the decrease in the ratio coefficient is still very small for each year.

The phenomenon of investment openness in Indonesia with social inequality in society is a social reality that needs to be considered. Just as investment in domestic investment in Indonesia is increasing in Indonesia. The number of domestic investment in Indonesia in 2017 was IDR 262.3 trillion, which is greater than in 2016, which started at IDR 216.2 trillion.

One form of domestic investment is the construction of modern stores. The construction and arrangement of modern stores has been established by the Government in clear legal products. In the Minister of Trade Regulation, Number 70 in 2013, the modern Shop is a shop with a self service system, minimarket, supermarket, department store, hypermarket, or wholesaler in the form of a Grocery.

\section{Previous research of Small Medium Enterprise (SME) empowerment in global and Indonesia}

Sulong et al. [4] conducted research related to the development of SME in Malaysia using Material Flow Cost Accounting. Furthermore in Korea, Shin et al [5] explores SME ability in reading the market situation and its influence on operational performance and companies by using Structural Equation Modeling. Besides, Kato and Charoenrat [6] conducted a research in Thailand, Caldera et al [7] in Australia, Mamman et al [8] in Africa.

Based on studies related to SME empowerment that have been carried out in various countries it is an attempt to improve the competence of SME both internally such as financial management, willingness, commitment, good work ethics, risk management and from an external perspective such as learning from entrepreneurs who has been successful in making a sustainable business and evaluating government policies related to SME empowerment.

In Indonesia, research related to the development of SME with the concept of partnership policy has been carried out. Rachmaya and Prabawati [9] conducted a study on the Implementation of Business Partnership Policies in Sidoarjo Regent Regulation Number 20 of 2011 concerning Minimarket Arrangement in Sidoarjo Town using the implementation model according to Grindle. Then, Sari [10] conducted a study on the 
Effect of Minimarket Existence on Survival of Grocery Stores in Sidoarjo Town using Nearest Neighbor Analysis (NNA). Besides, Triyuda [11] conducted a research in Surabaya, Anshori and Santoso [12] in Blora, and Widiastuti and Santoso [13] in Semarang.

In this regard, it is considered important to conduct research related to the implementation of a supermarket department partnership policy with SME with a case study approach.

\section{Research methodology}

The research method used is descriptive research method with case study design. This study used a qualitative approach through interviews with SME that established partnership relationships with X Supermarket. In analyzing the implementation of partnership policies between supermarkets and SME, the authors used Policy Implementation Theory by Van Meter And Van Horn (1975).

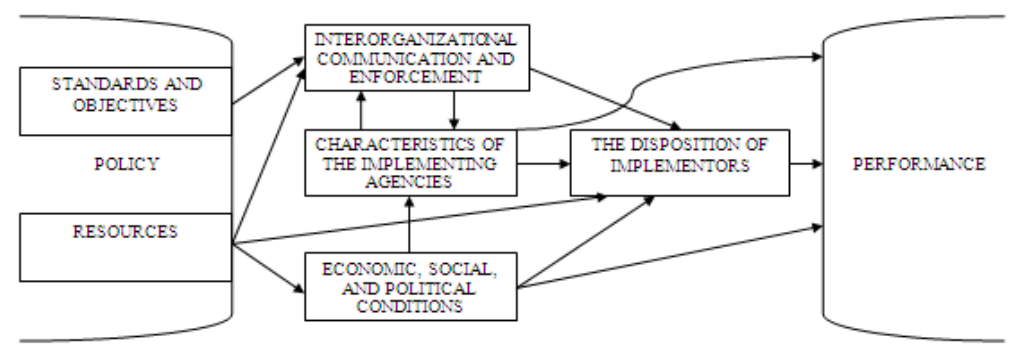

Fig. 1. Conceptual framework of theory.

\section{Discussion}

The type of superior product of the Sidoarjo Town which is marketed at X Supermarket is a food and beverage product. SME products marketed can be seen in Figure 2.
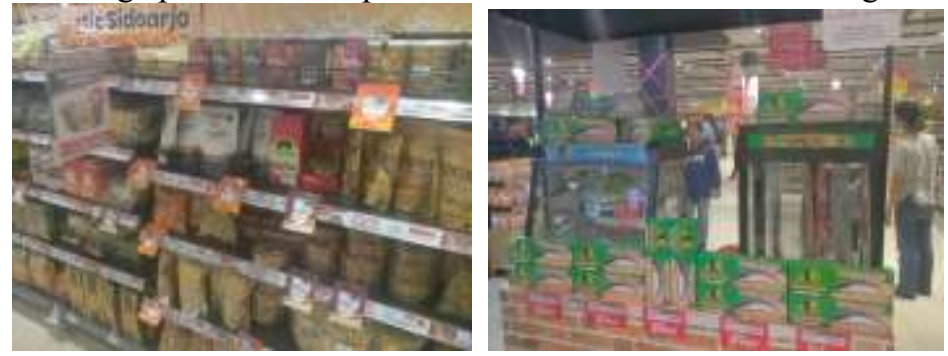

Fig. 2. SME products in X supermarket.

According to Van Meter and Van Horn (1975), there are six variables that affect the performance of implementation, including:

1. Standards and Policy Targets

The legal basis underlying the Partnership Policy between Supermarkets and SME is Minister of Trade Number Regulation Number 56 of 2014 and Law Number 7 of 2014. In addition, it also affirms that the Government and / or Regional Government in accordance with its authority regulate the development, structuring and coaching that are equal and 
equitable towards the People's Market, shopping centers, supermarkets, and cooperatives to create business certainty and a balanced cooperation relationship between suppliers and retailers while still paying attention to alignments with cooperatives as well as micro, small and medium enterprises.

\section{Resources}

In terms of human resources, the parties involved in carrying out partnership activities are Sidoarjo Town Government, SME and X Supermarket. The institutions involved in this government policy are Department of Industry and Trade and Department of Investment and Integrated One-Stop Service. of Investment and Integrated One-Stop Service is authorized to publish a Supermarkets Trading Business License. One of the conditions for obtaining a permit for a Trading Business License is a recommendation from Department of Industry and Trade. One of the requirements that must be fulfilled in the recommendation process is a partnership plan between Supermarkets and SME. In undergoing the partnership process, SME are considered to be less active in supervising their products at X Supermarkets. Only a few SME have the initiative to become direct sales at the sales location to find out their market tastes. In addition, the X Supermarket also lacks empowering the potential available to SME. X Supermarket does not provide special training or guidance in order to survive in product competition in the supermarket market. In terms of financial resources, the process of submitting a Supermarkets Business License to the Department of Industry and Trade is free. As for the financing and profit mechanism in the partnership process, the cooperation contract is carried out by the related parties, namely X Supermarket and SME. In terms of facilities and infrastructure, X Supermarket has provided special shelves for SME products located in the Product Sales Store. In addition, there are special posts displayed by X Supermarket so that they can differentiate from other non-SME products.

\section{Communication between Organizations and Strengthening Activities}

In carrying out Partnership activities between Supermarkets and SME, the implementing parties who contribute to these activities should conduct more intense communication. But unfortunately communication is poorly intertwined. The SME is represented by one person who is appointed as a Supervisor representing the interests of SME and discussing with the $\mathrm{X}$ Supermarket. $\mathrm{X}$ Supermarket is considered to be less intense in establishing communication with the supervisors of the SME, so that there are no regular meetings held by X Supermarket to receive suggestions and criticisms for the course of the partnership program. It causes the Supervisor who must have the initiative first if there are obstacles in marketing of SME products in X Supermarkets. Thus, the basic principles of partnership that help and work together are not well established because the main goal of the partnership is not only in addition to improving the economy of a sustainable SME, but also focusing on the transfer of knowledge.

\section{Characteristics of Implementing Agents}

The Implementing Agent of the Partnership Policy between Supermarkets and SME is the Sidoarjo Town Government, X Supermarket and SME. Sidoarjo Town Government is authorized to issue a Supermarkets Business License. In carrying out its duties, the Government works in accordance with the regulation. This X Supermarket is one of the supermarkets in Sidoarjo Regency with the hypermarket category. SME are local business community assisted by Department of Industry and Trade, which cooperates with X Supermarkets, which amounts to 20 people. 20 of these SME have been selected by $X$ Supermarket according to the standards of products entering retail. In order for the partnership between X Supermarket and SME to work well, X Supermarket with SME have 
signed a Memorandum of Understanding (MoU) known by the Sidoarjo Regent. The signing of the $\mathrm{MoU}$ is considered important so that the $\mathrm{X}$ Supermarket can undergo the obligation of partnership with SME properly and correctly. Thus, it can be seen that the pattern of relations between implementing agents of the Partnership Policy between Supermarkets and SME is well.

\section{Implementor Disposition}

The response of the implementor is quite good because there has been a signing of a Memorandum of Understanding between the X Supermarket, SME, and Sidoarjo Regent. But, after establishing a partnership, there are still obstacles. In terms of commitment and honesty, SMEs are still not good because SMEs only look at the profit side so if they suffer losses, the partnership will not continue. In addition, there are some SMEs that are still less honest, so they tend to force their products to enter X Supermarket even though they are not in accordance with modern retail concepts. This results in the losses experienced by the SME. In addition, X Supermarket although still committed in establishing contracts in accordance with contracts, but are less intense in establishing communication relationships and empowering SME properly. X Supermarket tend to only provide facilities to sell products but lack training and technical guidance to SME to grow their businesses. In addition, X Supermarket are often late in reimbursing funds for sold products, thus harming the SME.

\section{Social, Economic and Political Conditions}

The political elites of the Sidoarjo Town Regional Representative Council and Sidoarjo Town Government support the existence of a Partnership Policy between Supermarkets and SMEs. This support can be obtained in Sidoarjo Regent's Regulation Number 36 of 2016. In the regulation, every application for a Modern Shop Business License is obliged to partner with SME. Thus, the Partnership Policy between Supermarkets and SME has the support of the political elite.

Table 1. Result analysis of Van Meter and Van Horn theory.

\begin{tabular}{|c|l|c|c|c|}
\hline No. & \multicolumn{1}{|c|}{ Variable } & \multicolumn{3}{c|}{ Analysis } \\
\cline { 3 - 5 } & & High & Medium & Low \\
\hline 1. & Standards And Policy Targets & $\sqrt{ }$ & \\
\hline 2. & Resources & $\sqrt{ }$ & & \\
\hline & - Financial & & & $\sqrt{ }$ \\
\hline & - Human Resources & $\sqrt{ }$ & & \\
\hline & - Physical (Facilities and Infrastructure) & & & $\sqrt{ }$ \\
\hline 3. & Communication & $\sqrt{ }$ & & \\
\hline 4. & Characteristics of Implementing Agents & & & $\sqrt{ }$ \\
\hline 5. & Implementor Disposition & $\sqrt{ }$ & & \\
\hline 6. & Social, Economic and Political Conditions & & \\
\hline
\end{tabular}

\section{Conclusion}

Based on the analysis, it can be concluded that the implementation of the Supermarkets and SME partnership policy is still not good. There are several things that need to be improved so that the partnership policy can run optimally, such as Human Resources, Communication Between Organization and Strengthening Activities, and Implementor Disposition. Human Resources need to be improved because related human resources such as SMEs still lack the initiative to develop their businesses in a modern retail scale, while Supermarkets X 
does not carry out technical coaching so that SMEs can have competitiveness in the modern market. In the case of Communication Between Organization and Strengthening Activities still many things need to be improved because there is no intense communication such as regular meetings between Supermarkets $\mathrm{X}$ and SME. In addition, the disposition implementor must also be improved. There should be good management governance between Supermarkets X and SMEs in running partnerships, so that no one party is harmed. Thus, PPP is considered still not optimal in reducing poverty and promoting sustainable economic development for SMEs.

\section{References}

1. BKPM, Real. penanaman modal PMDN dan PMA Triwul IV (2018)

2. W. Bank, Econ prfl of Indonesia, Intl. Fin. (2018)

3. BPS. Inequality of pop ee In Indonesia September 2017 1-2 (2018)

4. Sulong, Sulaiman, and Norhayati, MFCA enablers and barriers: the case of a MY SME. JOCP 108, 1365-1374 (2015)

5. H. Shin, J. N. Lee, D. S. Kim, H. Rhim. IJPE, 168, 181-196 (2015)

6. M. Kato \& T. Charoenrat, IJDRR, 577-587 (2018)

7. Caldera, Desha, \& Dawes, JOCP 177, 338-349 (2018)

8. A. Mamman, J. Bawole, M. Agbebi, A. R. Alhassan. J. Bus. Res., 0-1 (2018)

9. V. Meter \& V. Horn, AAS 6, 445-88 (1975)

10. V. Rachmaya \& I. Prabawati, Implementasi kebijakan kemitraan usaha pada Perbup Sda No. 20 Thn 2011 ttg penataan minimarket di Kab. Sda (2011)

11. E.N.L. Sari, Pengaruh keberadaan minimarket terhadap kelangsungan hdp toko kelontong di Kec. Sda, Kab. Sda (2012)

12. M.I. Triyuda, Eval. kebijakan penataan usaha TM dan minimarket (studi evaluasi Perda Sby No. 8 thn 2014 ttg penataan toko swalayan di Kota Sby (2017)

13. S. Anshori, Evaluasi kebijakan penataan Psr. Trad., PP dan TM di Kab. Blora (2016)

14. D. Widiastuti \& R.S. Santoso, Eval. Kebijakan Perwakil Smg No. 05 thn 2013 ttg penataan TM minimarket Kota Smg (2017)

15. B. Winarno, CAPS (2012) 